\title{
Peran teman sebaya dalam pembentukan karakter siswa madrasah tsanawiyah
}

\author{
Yusuf Kurniawan a, 1*, Ajat Sudrajat ${ }^{\text {b, } 2}$ \\ ${ }^{a, b}$ Program Studi Pendidikan IPS, Program Pascasarjana, Universitas Negeri Yogyakarta, Yogyakarta, \\ Indonesia \\ ${ }^{1}$ yusufkurniawan30.yk@gmail.com*; ajat@uny.ac.id \\ *korespondensi penulis
}

\begin{tabular}{ll}
\hline Informasi artikel & ABSTRAK \\
\hline Kata kunci: & Penelitian ini bertujuan untuk mengetahui peran teman sebaya dalam pembentukan \\
Siswa, & karakter siswa di MTs YAPI Pakem. Penelitian ini merupakan penelitian kualitatif yang \\
Kelompok teman & menggunakan pendekatan fenomenologi. Pengumpulan data melalui observasi, \\
sebaya, & wawancara, dan dokumentasi. Keabsahan data diperoleh melalui triangulasi. Analisis \\
Sekolah & data menggunakan analisis model yang dikembangkan oleh Miles \& Huberman. Hasil \\
& penelitian adalah sebagai berikut. 1. Teman sebaya memiliki berbagai peran penting bagi \\
& siswa MTs YAPI Pakem, yaitu: a. memberikan dukungan terhadap siswa, b. mengajarkan \\
& berbagai keterampilan sosial, c. menjadi agen sosialisasi bagi siswa, dan d. menjadi \\
& model atau contoh berperilaku bagi siswa lain. 2. Teman sebaya memiliki peran dalam \\
& membentuk berbagai karakter siswa, yaitu religius, toleransi, disiplin, kerja keras, rasa \\
& ingin tahu, bersahabat, peduli lingkungan, peduli sosial, membangkang, dan agresif.
\end{tabular}

\begin{tabular}{ll}
\hline Keywords: & ABSTRACT \\
Students, & This study aimed to reveal the role of peers in the character building of the students of \\
Peer groups, & MTs YAPI Pakem. This research was a qualitative study using the phenomenological \\
School. & The data validity of this study was obtained through technique triangulation. The data \\
& analysis used the analysis model developed by Miles \& Huberman. The findings of this \\
study were as follows. 1. Peers played multiple roles for students of MTs YAPI Pakem, for \\
instance: a. giving support to students, b. teaching a number of social skills, c. to become \\
agents of socialization for other students, and d. to become models or examples on how to \\
behave for other students. 2. The peer interaction had effects on building the characters \\
of religiosity, tolerance, discipline, perseverance, curiosity, friendliness, environmental \\
care, social care, rebellion, and aggression.
\end{tabular}

Copyright (C) 2018 Yusuf Kurniawan dan Ajat Sudrajat. All Right Reserved

\section{PENDAHULUAN}

Perilaku masyarakat Indonesia mengalami perubahan yang signifikan. Hal tersebut ditunjukkan dengan perubahanperubahan yang terjadi dalam berbagai aspek. Pola interaksi, pola pergaulan, dan dinamika kehidupan masyarakat, kini cenderung mengabaikan nilai, norma, akhlak, moral maupun budi pekerti. Padahal, selama ini, bangsa Indonesia dikenal sebagai bangsa ketimuran, bangsa yang memiliki nilai-nilai budi pekerti luhur, kerja keras, berbudaya, dan beradab. Gejala-gejala tersebut menunjukkan bahwa semua lapisan masyarakat, mulai dari kelompok elite, masyarakat biasa, remaja hingga anak-anak sedang mengalami krisis karakter. Sulton (2016, hal. 39) mengatakan bahwa berbagai bentuk perubahan perilaku tersebut akan menyebabkan maraknya berbagai tindakan a-moral di tengah-tengah masyarakat atau sering disebut demoralisasi. 
Fenomena demoralisasi kini melanda bangsa Indonesia. Fenomena demoralisasi telah memicu terjadinya krisis karakter. Sidi (2014, hal.74) memaparkan bahwa krisis karakter adalah hilangnya nilai-nilai/norma yang seharusnya dipegang teguh dalam kehidupan sehari-hari sehingga perilakunya menyimpang dari nilai-nilai yang ada dalam masyarakat. Krisis karakter tersebut berakar pada menurunnya kualitas moral bangsa akibat disorientasi nilai Pancasila, bergesernya nilai etika kehidupan berbangsa, memudarnya kesadaran terhadap nilai budaya bangsa, dan melemahnya kemandirian bangsa.

Berbagai bentuk krisis karakter di Indonesia seperti maraknya korupsi, kebohongan dan pembodohan publik, maraknya aksi pornografi, kriminalitas serta penggunaan dan peredaran NAPZA menunjukkan kualitas manusia Indonesia yang masih rendah. Hal tersebut tentu sangat berimbas pada moralitas masyarakat, terutama kalangan remaja. Padahal, masa remaja merupakan masa peralihan, masa yang sangat penting bagi pembentukan karakter remaja. Dengan maraknya fenomena tersebut, bukan tidak mungkin perkembangan dan pembangunan karakter di usia remaja akan sangat terpengaruh, dan justru mengarah pada kemerosotan karakter.

Saat ini krisis karakter telah melanda lingkungan remaja. Hal tersebut ditandai dengan banyaknya tindakan remaja yang menyimpang dari norma sosial masyarakat.
Salah satu penyebabnya adalah kegagalan proses sosialisasi karena bergesernya peran agen sosialisasi pada remaja, dari lingkungan keluarga ke dalam kelompok sosial. Kelompok sosial mampu menjadi agen sosialisasi yang sangat berpengaruh bagi pembentukan pola perilaku anak atau remaja.

Terlebih lagi, kelompok sosial tersebut beranggotakan teman sebaya, tentu akan lebih mudah berpengaruh bagi remaja.

Kiuru (2008, hal. 9) menyatakan bahwa pada saat anak-anak beranjak ke masa remaja, waktu yang dihabiskan dengan orang tua relatif menurun dibandingkan dengan teman sebaya, dan hubungan teman sebaya menjadi lebih diprioritaskan atau lebih dijadikan acuan daripada bimbingan dan manajemen orang yang lebih tua. Dumas (2012, hal.922) menyatakan bahwa selama masa remaja, remaja menghabiskan banyak waktu untuk berinteraksi dalam kelompok sebaya. Hal tersebut menunjukkan bahwa keberadaan teman sebaya sangat penting bagi remaja. Interaksi teman sebaya sangat penting dalam membentuk perilaku remaja. Hasil penelitian yang dilakukan oleh Ristiani (2008), dinyatakan bahwa terdapat hubungan positif yang sangat signifikan antara dukungan sosial teman sebaya dengan identitas diri pada remaja. Penelitian dari Mahendra (2010), dinyatakan bahwa terdapat hubungan positif yang signifikan antara pergaulan peer group dengan sikap pada siswa.

Hasil penelitian dari Susanto (2016), diperoleh data bahwa 1. Pola asuh orang tua 
memberikan pengaruh sebesar 16,30 \% terhadap karakter siswa SMP Negeri 25 Purworejo. 2. Pergaulan teman sebaya memberikan pengaruh sebesar 70,04 \% terhadap karakter siswa SMP Negeri 25 Purworejo. 3. Media televisi memberikan pengaruh sebesar 24,60 \% terhadap karakter siswa SMP Negeri 25 Purworejo. Hal ini menunjukkan bahwa pengaruh pergaulan teman sebaya lebih dominan dalam karakter siswa SMP Negeri 25 Purworejo dibandingkan pengaruh pola asuh orang tua dan media televisi. Dari beberapa hasil penelitian tersebut, diketahui bahwa teman sebaya mempengaruhi remaja dalam berbagai hal termasuk dalam hal sikap, identitas diri, maupun perilaku remaja yang nantinya akan berpengaruh terhadap karakter remaja.

Akan tetapi, hubungan teman sebaya tidak selalu dapat menghadirkan dukungan yang bersifat positif. Banyak juga pengaruh teman sebaya yang bersifat negatif, misalnya perilaku merokok pada remaja, perilaku seks bebas, dan bullying. Nasution (2007, hal.14) menyatakan bahwa kebanyakan perokok mulai merokok antara umur 11 dan 13 tahun, 85-95\% sebelum umur 18 tahun. Bahkan di Indonesia, 20\% total perokok adalah remaja dengan rentang usia 15-21 tahun. Hal tersebut berarti lingkungan teman sebaya yang positif, akan mendorong anak untuk mencapai perkembangan sosial yang matang. Namun, apabila lingkungannya bersifat negatif, maka perkembangan sosial anak akan terhambat dan mendekatkan anak pada krisis karakter.
Interaksi sosial dengan teman sebaya dapat terjadi di mana saja, salah satunya di sekolah. Sama halnya dengan perilaku remaja pada umumnya, perilaku anak di sekolah juga banyak menampakkan gejala demoralisasi sebagai akibat dari makin menurunnya kualitas nilai-nilai karakter pada siswa. Berbagai permasalahan seperti tawuran antar pelajar, mencontek, bullying, tindak asusila, perusakan fasilitas sekolah dan tindakan melanggar kedisiplinan yang lain seperti sudah menjadi rutinitas keseharian dari kebanyakan siswa, terutama di jenjang pendidikan menengah. Anak remaja jaman sekarang cenderung membenarkan anggapan dari kelompoknya, tanpa menghiraukan benar atau tidaknya di mata umum.

Muslich (2011, hal. 35) menjelaskan bahwa terdapat sepuluh tanda jaman yang harus diwaspadai. Tanda-tanda tersebut yaitu meningkatnya kekerasan di kalangan remaja, penggunaan kata-kata yang buruk, pengaruh teman sebaya yang kuat dalam tindak kekerasan, meningkatnya kegiatan merusak diri, semakin kaburnya pedoman moral, menurunnya etos kerja, rendahnya rasa hormat kepada orang tua dan guru, rendahnya tanggung jawab, budaya tidak jujur, serta adanya rasa curiga dan benci antar sesama. Kesepuluh hal tersebut banyak terjadi di lingkungan sekolah saat ini. Sebagian besar siswa cenderung sudah kehilangan rasa malu dan tidak mau memperbaiki diri. Kesalahan tersebut dianggap wajar karena dilakukan 
oleh banyak orang, bersama-sama, dan dilakukan secara berulang-ulang.

Berkaitan dengan hubungan teman sebaya di sekolah, peneliti melakukan observasi di Madrasah Tsanawiyah (MTs) YAPI Pakem. Dari observasi yang dilakukan, pergaulan antar teman sebaya di sekolah tersebut terpisah dalam kelompok-kelompok kecil. Jika diperhatikan lebih lanjut, kelompok-kelompok kecil tersebut memiliki perilaku yang berbeda. Ada kelompok anak yang berperilaku disiplin, serta kelompok anak yang berperilaku membangkang.

Beberapa perilaku membangkang yang dilakukan siswa MTs YAPI Pakem antara lain melanggar tata tertib sekolah, bullying, coratcoret fasilitas sekolah seperti buku, dinding kelas, toilet, meja dan pintu, rendahnya sikap hormat siswa terhadap guru, rendahnya tanggung jawab siswa terutama dalam hal tugas-tugas sekolah, serta budaya tidak jujur seperti mencontek serta penggunaan bahasa dan kata-kata yang kasar, terutama dengan sesama teman. Berdasarkan fakta tersebut terlihat jelas bahwa kebiasaan dan perilaku anak pada saat melakukan kegiatan di sekolah sangat dipengaruhi oleh teman sebayanya. Maka dari itu, penting kiranya untuk mempelajari dan meninjau seberapa besar peran dan pengaruh teman sebaya terhadap pembentukan karakter siswa, karena masa remaja merupakan masa pertaruhan, di mana seorang siswa mulai memasuki dunia baru yang akan menentukan masa depannya kelak.
Berdasarkan latar belakang permasalahan di atas, maka dapat diidentifikasi permasalahan sebagai berikut: (1) fenomena demoralisasi telah melanda bangsa Indonesia dan menyebabkan terjadinya krisis karakter seperti maraknya korupsi, kebohongan dan pembodohan publik, aksi pornografi, kriminalitas, serta penggunaan NAPZA, (2) lingkungan teman sebaya tidak selalu dapat menghadirkan dukungan yang bersifat positif, tergantung pada kondisi realitas yang ada, (3) pergaulan teman sebaya di sekolah banyak menampakkan gejala demoralisasi seperti bullying, corat-coret fasilitas sekolah, rendahnya sikap hormat siswa terhadap guru, penggunaan bahasa yang buruk, rendahnya tanggung jawab siswa, budaya tidak jujur, dan pelanggaran kedisiplinan sebagai akibat dari makin menurunnya kualitas nilai-nilai karakter pada siswa.

Penelitian ini difokuskan pada pergaulan teman sebaya di sekolah yang banyak menampakkan gejala demoralisasi, sehingga rumusan masalahnya berkaitan dengan bagaimana peran teman sebaya bagi siswa di MTs YAPI Pakem, serta karakter yang muncul dalam pergaulan siswa di MTs YAPI Pakem. Hasil penelitian ini diharapkan dapat memberikan manfaat baik teoretis maupun praktis. Secara teoretis, hasil penelitian ini diharapkan bermanfaat untuk menambah pemahaman mengenai pentingnya peran teman sebaya bagi pembentukan karakter siswa. Manfaat praktis, sebagai wahana menambah pengalaman dalam dunia 
pendidikan dan lingkungan yang mempengaruhi pembentukan karakter siswa sesungguhnya, memberikan pengetahuan di sekolah.

kepada siswa untuk memilih kelompok teman

Penelitian dilaksanakan di MTs YAPI sebaya yang baik, memberikan pengetahuan kepada orang tua untuk lebih memberikan perhatian dan pengawasan terhadap Pakem, yang beralamat di Jalan Kaliurang Km 17, Dusun Labasan Kelurahan lingkungan pergaulan anak, serta memberikan Pakembinangun Kecamatan Pakem Kabupaten Sleman Provinsi Daerah Istimewa literatur kepada sekolah untuk lebih memberikan pengawasan kepada siswanya.

\section{METODE}

Penelitian ini menggunakan metode penelitian kualitatif. Somantri (2005, hal.58) menyatakan bahwa penelitian kualitatif memiliki ciri yaitu informasi yang didapatkan berupa ikatan konteks yang akan menggiring pada pola-pola atau teori yang akan menjelaskan fenomena sosial. Penelitian kualitatif akan menghasilkan deskripsi data berupa kata tertulis, lisan dari orang, serta perilaku yang diamati. Jenis penelitian kualitatif hanya bersifat mendeskripsikan atau menggambarkan kondisi objek penelitian, bukan menguji hipotesis. Penelitian kualitatif yang dilakukan menggunakan pendekatan fenomenologis. Kuswarno (2006, hal. 49) mengatakan bahwa fenomenologis merupakan salah satu pendekatan dalam penelitian kualitatif, yang berupaya menggambarkan fenomena dari suatu komunitas tertentu menurut pandangan mereka sendiri. Peneliti bermaksud untuk mengungkap fenomena sosial di kalangan remaja untuk mengetahui seberapa besar peran teman sebaya tersebut dalam

Yogyakarta. Peneliti tertarik untuk melakukan observasi di MTs YAPI Pakem karena latar belakang siswa yang beraneka ragam, serta pandangan negatif yang sering disematkan pada sekolah berkaitan dengan perilaku siswanya. Penelitian dilaksanakan mulai tanggal 6 April sampai 6 Juli 2017.

Pengumpulan data dilakukan dengan wawancara, observasi dan dokumentasi. Data yang diperoleh dicatat dalam catatan lapangan yang berbentuk deskriptif, mengenai apa yang dilihat, didengar, dirasakan dan dialami oleh subjek penelitian. Reduksi data meliputi tahap pemilihan, pemusatan, penyederhanaan dan transformasi data kasar yang diperoleh di lapangan pada saat proses pengumpulan data. Reduksi data digunakan untuk mengklasifikasikan aspek penting yang akan dikaji. Data reduksi adalah bagian dari analisis, analisis yang mempertegas, memperpendek, membuat fokus, membuang hal yang tidak penting dan mengatur data sedemikian rupa sehingga ditemukan kesimpulan akhir. Penyajian data digunakan untuk memahami apa yang sedang terjadi, apa yang harus dilakukan selanjutnya untuk dianalisis dan diambil tindakan yang dianggap perlu. Tahap terakhir adalah penarikan 
kesimpulan. Pada tahap ini, peneliti berusaha mencari makna dari komponen yang disajikan dengan mencatat pola, keteraturan, konfigurasi, sebab akibat dan proporsi dalam penelitian.

\section{HASIL DAN PEMBAHASAN}

Teman sebaya adalah individu yang memiliki kedudukan, usia, status, dan pola pikir yang hampir sama. Blazevic (2016, hal. 46) mengatakan bahwa teman sebaya didefinisikan sebagai kelompok sosial yang terdiri dari orang-orang dengan usia, pendidikan atau status sosial yang serupa. Santrock (2003, hal. 129) mengemukakan bahwa teman sebaya adalah anak dengan usia atau tingkat kedewasaan yang sama. Berbagai persamaan tersebut berdampak pada pola interaksi yang dilakukan yaitu interaksi secara berkelompok. Persamaan tersebut kemudian memunculkan berbagai kelompok pergaulan teman sebaya, yang akan mempengaruhi perilaku anggotanya sesuai dengan karakteristik kelompok masing-masing. Kiuru (2008, hal.9) menyatakan bahwa lingkungan sosial terdekat seperti keluarga dan teman sebaya menjadi lingkungan signifikan bagi perkembangan remaja. Calvo (2008, hal. 2) menyatakan bahwa perilaku individu dipengaruhi oleh rekan mereka, sehingga teman sebaya menjadi rujukan (reference group) dalam mengembangkan perilaku remaja.

Lingkungan teman sebaya tentunya memiliki peran bagi remaja di mana pun berada, tak terkecuali di sekolah. Lingkungan teman di sekolah juga memiliki peran tersendiri bagi siswa di sekolah tersebut. Wulansari (2009, hal. 106) menjelaskan bahwa peran adalah konsep tentang apa yang harus dilakukan oleh seseorang, meliputi tuntutan perilaku dari masyarakat terhadap seseorang, dan menjadi perilaku individu yang penting bagi struktur sosial masyarakat. Merton (2007, hal. 110) menjelaskan bahwa peran adalah pola tingkah laku yang diharapkan masyarakat dari orang yang menduduki status tertentu. Peran akan menentukan apa yang dilakukan seorang individu bagi masyarakat, serta kesempatan apa yang diberikan masyarakat kepada individu tersebut. Peran sangat penting karena dapat mengatur perilaku seseorang, dan menyebabkan seseorang dapat meramalkan perbuatan orang lain pada batas tertentu, sehingga seseorang dapat menyesuaikan perilakunya sendiri dengan perilaku orang dalam kelompoknya.

Hasil penelitian yang dilakukan di MTs YAPI Pakem, menunjukkan bahwa keberadaan teman sebaya memiliki berbagai peran bagi siswa. Berdasarkan hasil temuan data wawancara, observasi, maupun dokumentasi, diperoleh hasil bahwa teman sebaya memiliki berbagai peran bagi siswa di sekolah. Pertama, teman sebaya berperan untuk memberikan dukungan sosial, moral, dan emosional bagi siswa. Santrock (2003, hal. 27) mengatakan bahwa teman sebaya berperan untuk memberikan dukungan fisik, dukungan ego, perbandingan sosial, dan 
perhatian. Dukungan-dukungan tersebut diwujudkan melalui sikap saling perhatian antar siswa, saling memberikan nasihat dan masukan ketika siswa mendapat masalah, saling bercerita, berkeluh kesah, dan saling mengadu ketika ada masalah. Bahkan siswa lebih memilih untuk bercerita mengenai segala permasalahan kepada teman sebaya daripada orang tua atau guru. Hal tersebut karena siswa lebih merasa nyaman untuk bercerita dengan teman sebayanya.

Perasaan nyaman yang dihadirkan oleh teman sebaya dalam pergaulannya di kelompok teman sebayanya masing-masing berkaitan dengan kenyamanan sosio kultural, yaitu kenyamanan yang berkaitan dengan hubungan interpersonal siswa, antara lain nyaman dalam bercerita, nyaman dalam bertukar pikiran, serta nyaman dalam melakukan kegiatan bersama. Sebagian besar siswa mengatakan bahwa mereka merasa nyaman dengan teman kelompoknya, nyaman untuk saling bercerita, mencurahkan isi hati (curhat), atau cerita berbagai masalah yang berkaitan dengan kehidupan pribadi.

Kedua, teman sebaya berperan untuk mengajarkan berbagai ketrampilan sosial bagi siswa. Desmita (2009, hal. 220) menyatakan bahwa salah satu peran teman sebaya adalah meningkatkan ketrampilan sosial. Ketrampilan sosial tersebut bermacammacam. Salah satu ketrampilan sosial yang muncul dalam pergaulan teman sebaya di MTs YAPI Pakem adalah kerja sama. Mayoritas siswa menyatakan bahwa mereka belajar bekerja sama dalam berbagai hal seperti dalam hal belajar, mengerjakan tugas, dan menjalankan hobi.

Kerjasama tercermin pada saat siswa mengerjakan tugas atau pekerjaan rumah. Siswa mengungkapkan bahwa mereka biasanya saling bertanya mengenai tugas sekolah, kemudian belajar bersama di rumah salah satu siswa. Selain itu, pihak sekolah juga menyediakan wadah untuk mengembangkan ketrampilan sosial siswa melalui kegiatan ekstrakurikuler. Dalam kegiatan ekstrakurikuler tersebut, siswa banyak belajar mengenai kerja sama, seperti pembagian kerja dalam kegiatan jurnalistik, pembagian kerja dalam prakarya, pramuka, dan yang lainnya. Dari hal tersebut, maka siswa akan belajar untuk bekerja sama menyelesaikan tugas, serta belajar bertanggungjawab sesuai tugas masing-masing.

Selain itu, ada beberapa anak yang melakukan kerja sama dalam melaksanakan hobi. Hobi tersebut disalurkan melalui kegiatan ekstrakurikuler di sekolah maupun dalam kegiatan keseharian siswa di luar sekolah. Kerjasama dalam hobi tersebut tercermin ketika anak-anak mengikuti kegiatan ekstrakurikuler, seperti olahraga. Dalam kegiatan tersebut, siswa akan belajar untuk bekerja sama dengan siswa lain dalam satu tim, untuk mencapai tujuan yang sama. Selain dalam kegiatan di sekolah, siswa juga sering menyalurkan hobi bersama di luar sekolah, seperti hobi bermain merpati. Siswa akan saling bekerja sama untuk membuat 
arena bermain merpati, menyiapkan tempat, menyiapkan bambu, rumah merpati, dan yang lainnya. Mereka juga mengatakan bahwa mereka saling kerja sama dalam merawat merpati.

Teman sebaya mengajarkan kemampuan untuk mengontrol diri siswa, sesuai dengan peran baru yang diperoleh dalam kelompoknya. Syamsu (2009, hal. 60) menyatakan bahwa lingkungan teman sebaya berperan memberikan kesempatan pada remaja untuk belajar berinteraksi dan mengontrol tingkah laku sosial mereka. Tingkah laku sosial diperolah dari peran sosial baru yang didapatkan remaja dalam kelompok pergaulannya. Ahmadi (2007, hal. 193-195) mengatakan bahwa teman sebaya menjadi sarana untuk mempelajari peranan sosial yang baru. Siswa menyatakan bahwa selama bergaul dengan teman sebaya, mereka belajar untuk mengontrol diri, tidak mudah marah, dan tidak mementingkan diri sendiri. Siswa juga belajar untuk memainkan peranan baru sebagai seorang sahabat, pemimpin, bahkan musuh bagi siswa lain. Dengan berbagai peran baru tersebut maka siswa akan belajar untuk mengontrol diri dan memerankan peran baru yang didapatkan dalam kelompoknya.

Teman sebaya juga mengajarkan ketrampilan memecahkan masalah. Schneider (2000, hal. 481) mengatakan bahwa peer groups atau teman sebaya mengajarkan berbagai hal kepada anak, salah satunya adalah mengajarkan ketrampilan dalam memecahkan masalah, terutama terhadap sesama anggota kelompok. Santrock (2007, hal. 206) juga menyatakan bahwa dalam lingkungan teman sebaya, anak belajar memformulasikan dan menyatakan pendapat mereka, menghargai sudut pandang sebaya, menegosiasikan solusi atas perselisihan secara kooperatif, dan mengubah standar perilaku yang diterima oleh semua. Siswa menyatakan bahwa dalam kelompok teman sebaya, mereka belajar untuk memecahkan berbagai permasalahan. Mereka belajar mencari solusi terbaik untuk memecahkan masalah yang mereka hadapi dengan berdiskusi mengenai permasalahan yang sedang dihadapi, kemudian mencari solusi bersama. Masalah tersebut juga beraneka ragam, seperti masalah belajar, masalah kedisiplinan, maupun masalah yang berkaitan dengan pribadi siswa. Terkadang, siswa juga meminta saran dari guru untuk menyelesaikan permasalahan, baik yang berkaitan dengan pelajaran maupun permasalahan pribadi.

Ketiga, teman sebaya berperan sebagai agen sosialisasi bagi siswa lainnya. Sosialisasi merupakan proses penyesuaian diri individu dengan lingkungannya, berinteraksi, mengembangkan relasi, dan belajar untuk bertingkah laku berdasarkan patokan atau norma yang diakui oleh masyarakat. Teman sebaya berperan sebagai salah satu agen sosialisasi yang paling berpengaruh bagi siswa, sehingga teman sebaya menjadi rujukan (reference group) dalam mengembangkan perilaku siswa lainnya. Siswa akan mempelajari berbagai 
kemampuan yang baru, yang berbeda dengan apa yang mereka dapatkan dalam keluarga. Siswa akan mempelajari nilai, norma, kultur, peran, dan hal lain yang dibutuhkan untuk memungkinkan partisipasinya yang efektif di lingkungan yang lebih luas, khususnya di lingkungan sekolah.

Teman sebaya sebagai agen sosialisasi tercermin dari kebiasaan mereka untuk saling mengingatkan mengenai aturan-aturan sekolah. beberapa siswa mengatakan bahwa mereka akan menegur teman yang lain ketika melanggar aturan seperti membuang sampah sembarangan, berperilaku tidak disiplin, serta membolos sekolah atau membolos kegiatan ekstrakurikuler. Dengan saling mengingatkan, saling menegur, terutama dalam hal kedisiplinan, maka hal tersebut secara tidak langsung mencerminkan bahwa teman sebaya dapat menjadi salah satu agen sosialisasi siswa di lingkungan sekolah.

Selain itu, teman sebaya juga bisa menjadi model atau contoh berperilaku siswa. Kelompok teman sebaya ikut menentukan pembentukan sikap untuk berperilaku sesuai dengan kelompoknya. Bazid (2015, hal.786) mengemukakan bahwa "peers are an important factor in influencing the formation of a person's personality and self-formation.”, teman sebaya merupakan faktor penting dalam mempengaruhi pembentukan kepribadian dan pembentukan diri seseorang. Hal tersebut berarti keberadaan kelompok teman sebaya akan memberikan dukungan kepada remaja untuk berperilaku dan bersosialisasi dengan baik sesuai dengan aturan yang berlaku

Kimani (2013, hal.14) menyatakan bahwa tekanan teman sebaya menjadi faktor penting bagi pembentukan perilaku siswa. Pembentukan perilaku dan modifikasi perilaku siswa sangat dipengaruhi oleh tekanan teman sebaya dan pemodelan yang diberikan oleh rekan mereka. Dalam pergaulan teman sebaya di MTs YAPI Pakem, teman sebaya memberikan contoh untuk berperilaku sesuai aturan sekolah, misalnya berpakaian rapi, memasukkan baju, menjaga kebersihan lingkungan, serta membuang sampah pada tempatnya. Siswa akan memberikan teguran kepada siswa lain manakala ada yang melanggar peraturan sekolah. Bahkan, ada juga beberapa siswa yang memberikan contoh untuk membuang sampah pada tempatnya ketika ada teman lain yang membuang sampah sembarangan. Siswa juga berperan memberikan contoh berperilaku sopan kepada guru. Hal tersebut terlihat dari kebiasaan siswa ketika akan masuk ke dalam kelas, siswa berbaris kemudian mencium tangan guru terlebih dahulu. Hal tersebut akan diikuti oleh siswa yang lain dan dilakukan secara terus-menerus setiap pagi sebelum masuk ke dalam kelas.

Dari berbagai bahasan mengenai hasil penelitian tersebut, maka teman sebaya memiliki peran penting bagi siswa di MTs YAPI Pakem. Teman sebaya berperan untuk memberikan dukungan terhadap siswa, baik dukungan yang bersifat sosial, moral, dan 
emosional. Hal tersebut diwujudkan dengan perhatian teman sebaya manakala siswa lain memiliki masalah, saling memberikan motivasi, dan menjadi tempat nyaman untuk mencurahkan isi hati. Teman sebaya juga berperan untuk mengajarkan berbagai ketrampilan sosial, seperti kerja sama, tanggung jawab kemampuan berinteraksi, mengontrol diri, dan memecahkan masalah. Teman sebaya juga berperan sebagai agen sosialisasi bagi siswa lain. teman sebaya mengajarkan nilai, norma, kultur, peran, dan hal lain yang dibutuhkan anak untuk memungkinkan partisipasinya yang efektif di lingkungan yang lebih luas. Selain itu, teman sebaya juga berperan untuk menjadi model atau contoh berperilaku siswa lain di lingkungan sekolah.

Peran kelompok teman sebaya beraneka ragam. Teman sebaya berperan untuk memberikan dorongan dan motivasi kepada siswa lain, menjadi model atau contoh berperilaku bagi siswa lain, menjadi agen sosialisasi, dan mengajarkan ketrampilan sosial kepada siswa yang lain. Berdasarkan peran kelompok teman sebaya tersebut, maka karakter siswa akan terbentuk dengan sendirinya, sesuai dengan aturan dalam kelompok serta kebiasaan yang sering dilakukan dalam kelompok. Schneider (2000, hal. 481) menyatakan bahwa remaja dalam sebuah kelompok memiliki sebuah ikatan, akan terikat dengan kepentingan dan aturan dalam kelompoknya. Hasilnya, karakter sosial kelompoknya mungkin akan dijadikan panduan bagaimana untuk mereaksi segala hal dan dijadikan pedoman dalam melakukan interaksi serta pedoman berperilaku individu.

$$
\text { Kebiasaan yang dilakukan dalam }
$$
kelompok, akan mempengaruhi kepribadian anggotanya, dan akan menjadi acuan berperilaku anggotanya, sehingga secara tidak langsung, karakter masing-masing anggota akan terbentuk sesuai dengan karakter sosial yang dibangun di dalam kelompok pergaulannya. Kebiasaan itu tentunya beraneka ragam, kebiasaan yang positif, atau negatif, tergantung kelompok teman sebaya yang seperti apa yang diikutinya. Misalnya, teman sebaya berperan sebagai agen sosialisasi yang mengajarkan kedisiplinan kepada siswa lain di sekolah. Apabila perilaku disiplin tersebut ditanamkan terus menerus dalam pergaulan teman sebaya dalam kelompok, maka lama kelamaan perilaku disiplin akan menjadi karakter dalam kelompok tersebut, sehingga karakter disiplin akan terbentuk melalui pergaulan teman sebaya dalam kelompok tersebut.

Dalam pergaulan teman sebaya di MTs YAPI Pakem, teman sebaya memiliki pengaruh yang kuat dalam pembangunan karakter siswa. Susanto (2016, hal. 106) mengatakan bahwa Teman sebaya adalah orang yang terdekat yang mampu berperan dalam pembentukan karakter anak atau siswa di dalam lingkungan pergaulannya. Terdapat beberapa karakter siswa yang muncul, yang bersifat positif maupun yang bersifat negatif, tergantung kebiasaan dan kegiatan yang 
dilakukan oleh kelompoknya. Untuk karakter positif, terdapat 8 karakter yang terbentuk dari pergaulan siswa dalam kelompok teman sebaya di lingkungan sekolah. Karakter tersebut antara lain religius, toleransi, disiplin, kerja keras, rasa ingin tahu, bersahabat / komunikatif, peduli lingkungan, dan peduli sosial. Untuk karakter yang lain, hanya dimiliki oleh sebagian kecil kelompok.

Karakter disiplin yang terbentuk dari pergaulan teman sebaya di MTs YAPI Pakem dibuktikan dengan semakin berkurangnya pelanggaran kedisiplinan yang dilakukan oleh siswa. Hal tersebut tidak terlepas dari peran teman sebaya yang memberikan tekanan kepada siswa lain untuk bersikap disiplin. Kimani (2013, hal. 14) menyatakan bahwa teman sebaya dapat digunakan untuk meningkatkan kedisiplinan sekolah, dengan pemberian tekanan untuk berperilaku disiplin dari teman sebayanya. Tekanan tersebut berupa teguran-teguran ketika ada siswa yang melanggar kedisiplinan, seperti mengeluarkan baju, bolos sekolah, dan bolos ekstrakurikuler. Kebiasaan untuk saling mengingatkan tersebut membuat siswa terbiasa untuk berperilaku disiplin. Selain itu, pihak sekolah juga memiliki program khusus untuk mensosialisasikan pentingnya kedisiplinan bagi siswa. Pihak sekolah biasanya bekerja sama dengan pihak kepolisian dalam hal penegakan kedisiplinan. Kegiatan yang dilakukan seperti latihan baris-berbaris, razia atribut sekolah, razia rambut, razia kendaraan bermotor, dan yang lainnya. Razia tersebut dilakukan secara mendadak, tidak ada waktu yang pasti. Namun, ketika ada beberapa kasus pelanggaran disiplin berat, biasanya pihak sekolah langsung melakukan razia.

Karakter religius dibuktikan dengan kebiasaan yang dilakukan teman sebaya untuk saling mengingatkan segala hal yang berkaitan dengan kegiatan keagamaan. French (2011, hal. 1623) pernah melakukan penelitian terhadap remaja muslim di Indonesia dan hasilnya menunjukkan bahwa ketika remaja berteman dengan lingkungan yang religius, maka tingkat kereligiusan remaja tersebut akan meningkat di tahuntahun berikutnya. Hal tersebut berarti berteman dengan lingkungan sebaya yang religius akan membuat seorang remaja lebih religius ke depannya. Dalam pergaulan teman sebaya di MTs YAPI Pakem, karakter religius dibentuk melalui berbagai kegiatan sekolah, antara lain tadarus pagi, baca tulis Al-Quran, solat duha, dan jamaah solat zuhur. Program tersebut dapat diterapkan dengan baik apabila ada kesadaran dari siswa untuk melakukannya. Di sinilah peran teman sebaya, teman sebaya selalu mengingatkan siswa lainnya untuk mengikuti tadarus pagi dengan benar, mengikuti ekstra BTAQ, dan rajin melaksanakan jamaah solat zuhur, sehingga apabila dilakukan secara terusmenerus, maka hal tersebut akan meningkatkan ketaatan beribadah siswa di sekolah.

Karakter peduli sosial terlihat ketika siswa mengalami kesulitan atau masalah, 
siswa yang lain akan membantu memberikan solusi, terutama dalam hal pelajaran, tugas sekolah, bahkan juga masalah-masalah yang terkait dengan kegiatan sekolah dan pribadi. Bazid (2015, hal. 756) mengatakan bahwa teman sebaya dipandang penting bagi seorang siswa, dia dapat memberi tahu mereka tentang perasaan, masalah, dan rahasianya. Teman sebaya menjadi sosok yang dianggap bisa menjadi tempat untuk saling bercerita dan memecahkan masalah. Selain itu, pihak sekolah mencanangkan program tutor sebaya bagi siswa. Melalui program tersebut, siswa dibiasakan untuk saling mengajari dan mendampingi siswa lain yang mengalami kesulitan atau permasalahan, dalam hal belajar atau masalah pribadi. Tutor sebaya akan membentuk karakter peduli sosial anak. Selain itu, sekolah juga mencanangkan program peduli berkendara dengan mengampanyekan pentingnya keselamatan berkendara bagi pengendara di jalan dengan terjun langsung di jalan sekitar sekolah. Sekolah juga memiliki program pembagian takjil gratis pada saat bulan puasa. Tujuannya adalah memberikan takjil kepada pengendara sepeda motor yang belum sempat untuk berbuka puasa. Kebiasaan tersebut akan membentuk karakter peduli sosial siswa.

Karakter toleransi tercermin manakala siswa menghargai kepentingan masingmasing, dan tidak memaksakan kehendak. Blazevic (2016, hal. 46) mengungkapkan bahwa pada masa pertengahan remaja, ketika anak mulai mengenal sahabatnya, anak-anak siap untuk kerja sama dan mencapai kesepakatan, bertoleransi, saling kepercayaan dan kerja sama, serta memiliki kedekatan yang intim. Karakter toleransi diterapkan oleh sebagian siswa ketika melakukan hobi bersama. Misalnya ketika bermain merpati, beberapa siswa mengatakan bahwa ketika akan bermain merpati mereka berangkat ke tempat bermain bersama-sama. Ketika ada anak yang tidak bisa ikut bermain karena tidak diperbolehkan oleh orang tuanya, teman yang lain memakluminya.

Karakter peduli lingkungan tercermin dari sikap siswa yang saling mengingatkan anggota kelompoknya apabila melakukan tindakan yang sekiranya merusak lingkungan atau mengotori lingkungan seperti corat-coret fasilitas sekolah, mengotori lingkungan sekolah dan membuang sampah sembarangan. Ditambah lagi dengan kebiasaan sebagian siswa yang memberikan keteladanan dengan memungut sampah dan membuangnya ke tempat sampah. Kimani (2013, hal. 14) menyatakan bahwa pembentukan perilaku dan modifikasi perilaku di antara siswa sangat dipengaruhi oleh tekanan teman sebaya dan pemodelan yang diberikan oleh siswa rekan mereka. Dengan adanya contoh yang diberikan oleh teman sebaya, maka siswa yang lain akan mengikutinya. Pembentukan karakter peduli lingkungan juga ditunjang oleh program sekolah, yaitu jalan sehat bersih, dan gerakan anti vandalisme. Program tersebut diwujudkan dengan kegiatan jalan sehat, sembari memungut sampah yang ada di 
sekitar lokasi jalan sehat. Untuk program anti vandalisme dilakukan dengan mengajak siswa untuk bersama-sama menghilangkan tulisan vandal yang berada di sekitar sekolah, membersihkan fasilitas sekolah seperti pintu dan meja dari coretan-coretan.

Karakter kerja keras dan rasa ingin tahu tercermin dari kebiasaan siswa dalam kelompok untuk memecahkan permasalahan yang berkaitan dengan kegiatan pelajaran. Pada saat ada kesulitan dalam memecahkan soal, siswa biasanya berdiskusi bersama dengan teman kelompoknya, apabila belum juga menemukan jawaban yang tepat, maka siswa akan bertanya kepada guru. Bahkan terkadang ketika ada waktu kosong, beberapa anak ada yang datang ke kantor untuk mencari guru mata pelajaran yang bersangkutan, kemudian menanyakan hal yang tidak dimengerti oleh mereka. Selain itu, pihak sekolah juga mewadahi pembentukan karakter kerja keras dan rasa ingin tahu dengan praktik pembelajaran langsung. Dalam beberapa mata pelajaran, siswa diberi kesempatan langsung untuk berinteraksi dengan masyarakat sekitar, atau dibawa langsung ke tempat pemotongan hewan. Hal tersebut dilakukan untuk menumbuhkan rasa ingin tahu siswa.

Akan tetapi, ada juga karakter negatif yang muncul dalam pergaulan teman sebaya di MTs YAPI Pakem. Terdapat beberapa kecenderungan karakter khusus yang sifatnya negatif muncul dalam pergaulan teman sebaya di MTs YAPI Pakem. Karakter tersebut adalah karakter membangkang dan agresi.
Karakter membangkang, ditunjukkan dengan masih adanya beberapa kelompok teman sebaya yang sebagian besar anggota kelompoknya sering melakukan tindakan menyimpang dari aturan sekolah, baik dalam hal kedisiplinan, atau dalam hal interaksi dengan teman sebayanya. Contoh ada beberapa siswa yang memang dengan sengaja mengeluarkan baju, bolos ekstra kurikuler, merokok di lingkungan sekolah, dan lainnya. Ketika ditanya dan ditegur, siswa yang bersangkutan akan menjawab dengan berbagai alasan.

Karakter agresi dilakukan oleh kelompok anak yang memiliki kebiasaan mengganggu, menggoda, dan sering membuat keributan. Sikap agresi yang ditunjukkan oleh sebagian siswa MTs YAPI Pakem adalah celotehancelotehan kasar, bullying dengan menyebut nama orang tua, dan sikap jahil lainnya. Salmivalili (2010, hal. 116) menyatakan bahwa perilaku bullying menjadi salah satu karakteristik anggota kelompok (klik/clique) yang sering mengganggu atau mengintimidasi kelompok siswa lainnya. Ferguson (2009, hal. 1) juga mengungkapkan bahwa teman sebaya menjadi faktor yang mendukung terciptanya karakter keras dan agresif pada remaja.

\section{SIMPULAN}

Teman sebaya memiliki berbagai peran penting bagi siswa MTs YAPI Pakem. Peran teman sebaya antara lain: (a) memberikan dukungan terhadap siswa, baik dukungan yang bersifat sosial, moral, dan emosional, (b) mengajarkan berbagai ketrampilan sosial, 
seperti kerja sama, kemampuan berinteraksi, mengontrol diri, dan memecahkan masalah, (c) menjadi agen sosialisasi bagi siswa, dan (d) menjadi model atau contoh berperilaku bagi siswa lain, (2) teman sebaya memiliki peran dalam membentuk berbagai karakter siswa, yaitu: disiplin, religius, bersahabat, peduli sosial, toleransi, peduli lingkungan, karakter kerja keras, rasa ingin tahu, membangkang, dan agresif.

\section{DAFTAR PUSTAKA}

Ahmadi, A. (2007). Psikologi sosial. Jakarta: PT. Rineka Cipta

Calvo. A.A., Eleonora P., \& Yves Zenou. (2008). Peer effects and social networks in education. Centre for research and analiysis of migration (CReAM) discussion pappe. No 14/8, November 15.

Bazid, N. \& Zainudin A. B. (2015). Peer influence on student misconduct. Proceeding of the International Conference on Social Science Research, ICSSR 2015 (e-ISBN 978-967-0792-04-0)

Blazevic, I. (2016). Family, Peer and School Influence on Children's Social Development. World Journal of Education Vol. 6, No. 2, 2016

Desmita. (2009). Psikologi perkembangan. Bandung : Remaja Rosdakarya.

Dumas. T.M., Wendy E. E., David A.W. (2012). Identity development as a buffer of adolescent risk behaviors in the context of peer group pressure and control. Journal of Adolescence 35, 917-927.

Ferguson, C. J., San M. C., \& Hartley, R. D. (2009). A multivariate analysis of youth violence and aggression: the influence of family, peers, depression, and media violence. The Journal of pediatrics, 155(6), 904-908.

French, D.C., etc. (2011). Friendship and the religiosity of Indonesian muslim. Journal youth adolescence, 2011: 40, pages 16231633.
Kimani, J.W. (2003). School factors influencing students discipline in public secondary schools in Kinangop district, Kenya. Academic Dissertation. University Of Nairobi

Kiuru, N. (2008). The role of adolescents peer groups in the school context. Academic dissertation. Jyvaskyla: University of Jyvaskyla.

Kuswarno, E. (2006). Tradisi fenomenologi pada penelitian komunikasi kualitatif: sebuah pengalaman akademis. Jurnal Mediator, Vol. 1 No.7.

Mahendra, S. (2010). Hubungan antara pola asuh orang tua dan pergaulan peer group (kelompok sebaya) dengan sikap pada siswa kelas XIIPS SMA Negeri 3 Surakarta Tahun Ajaran 2009/2010. Skripsi. Universitas Sebelas Maret, Surakarta.

Merton, R. K. (2007). The role-set: problems in sociological theory. The British Journal of Sociology, Vol. 8, No. 2, pp. 106-120.

Miles, B.M., \& Michael, H. (1994). Qualitative data analysis ( $\left.2^{\text {nd }} e d\right)$. London: SAGE Publications.

Muslich, M. (2011). Pendidikan karakter menjawab tantangan krisis multidimensional. Jakarta: Sinar Grafika Offset.

Nasution, \& Indri K. (2007). Perilaku merokok pada remaja. Jurnal. Medan: USU.

Ristianti, A. (2008). Hubungan antara dukungan sosial teman sebaya dengan identitas diri pada remaja di SMA Pusaka 1 Jakarta. Thesis Magister. Fakultas Psikologi Universitas Gunadarma, Jakarta.

Salmivalli, C. (2010). Bullying and the peer group: a review. Journal of Aggression and Violent Behavior . 15 (2010) 112-120.

Santrock, J.W. (2003). Adolesence: perkembangan remaja Edisi 6. Jakarta: Erlangga.

Santrock, J.W. (2007). Adolesence: perkembangan remaja Edisi 11. Jakarta: Erlangga. 
Schneider, B.H. (2000). International texts in developmental psychology $\left(1^{\text {st }}\right.$ ed). Routledge.

Sidi, P. (2014). Krisis karakter dalam perspektif teori struktural fungsional. Jurnal Pembangunan Pendidikan: Fondasi dan Aplikasi vol. 2, No. 1, 2014.

Somantri, G.R. (2005). Memahami metode kualitatif. Jurnal Makara, Sosial Humaniora Vol. 9 No. 2. Fisipol Universitas Indonesia.

Sugiyono. (2009). Memahami penelitian kualitatif. Bandung: Alfabeta.

Sulton. (2016). Realitas pendidikan nilai di lingkungan keluarga, sekolah dan masyarakat. Jurnal Dimensi Pendidikan dan Pembelajaran Vol. 5 Januari 2016. Universitas Muhammadiyah Ponorogo.

Susanto, A., \& Aman, A. (2016). Pengaruh pola asuh orang tua, pergaulan teman sebaya, media televisi terhadap karakter siswa SMP. Harmoni Sosial: Jurnal Pendidikan IPS, 3(2), 105-111.

Syamsu, Y (2008). Teori kepribadian. Bandung: Remaja Rosdakarya.

Wulansari, D. (2009). Sosiologi (konsep dan teori). Bandung: PT. Refika Aditama 